\title{
Karolina Koprowska
}

University of Wrocław

\section{Collage as an Act of Profanation? On the Works of Ewa Kuryluk*}

Keywords: Ewa Kuryluk, collage, postmemory, Holocaust.

\section{Introduction}

Those who want to speak about the experience of the Holocaust, an experience considered to be unprecedented and which escapes any customary notions, face a formidable challenge. Since many attempts at expressing and representing the Holocaust end in inevitable failure, the aesthetics of inexpressibleness has become, according to Marek Zaleski, the compulsory strategy, which slayed beauty and announced the triumph of the sublime. In the language of the sublime,

speaking of beauty is improper (although the victims and witnesses spoke of it in their "traditional" language). This language drew the extreme consequences of the long-time active tendency to differentiate beauty (into the beauty of a higher and lower tier) and may be the most clear-cut example of the manner in which aesthetics is colonised by ethics [Zaleski].

* Polish original: (2015) Kolaż jako akt profanacji? O twórczości Ewy Kuryluk. Wielogłos 1(23), pp. 43-55. 
The primacy of ethics over aesthetics is expressed in the imperative of the proper manner of speaking of the Holocaust and, at the same time, in Adorno's observation: "To write poetry after Auschwitz is barbaric" [Adorno, p. 34], which questions the feasibleness of the aesthetisation of this traumatic experience by literary or artistic means. This is why the most adequate manner of representation would be an academic and objective image of the events, which is, however, a utopian project, as Hayden White has already demonstrated in his Metahistory. Historical discourse was, therefore, quickly undermined and scholarly attention focussed on the discourse of memory and postmemory. Przemysław Czapliński also substantiates this shift of accent with generational change: the passing of the generation of direct witnesses and participants in the war events, and the "generation of postmemory" [Hirsch, passim] taking to the floor and trying to work through the legacy of the Shoah and the referential chasm of this experience. Following Lawrence L. Langer, Czapliński argues that

[...] previously art concerning the Holocaust did not represent the inexpressible but made evident the impossibility of representation. For some time now, we have had to reckon with the expression of something that is incomprehensible [Czapliński, pp. 205-206].

The change of attitude to the question of the expressibleness of the Holocaust involves the inevitable infringement of the established boundaries of propriety, which were supposed to ensure the objectivism and reliability of the accounts of war. Following Czapliński, we may assume that as of the 1990s, authors have released literary and artistic works that violate the prohibition of representation and employ aesthetic categories in their attempts to artistically work through the Holocaust. Frank Ankersmit says, "[...] when confronted with its ultimate challenge-accounting for the Holocaust - it is aesthetics, and not the categories of the factually true and the morally good, that history should appeal to" [Ankersmit, p. 62]. Therefore, many literary and artistic representations renounce the sublime ethically-oriented narrative and transgress the established conventions because "the slit through which representation trickles is an act of profanation of the Holocaust" [Czapliński, p, 204]. And this is not about the result of profanation or the sense of insult that may be caused by a given work, but about the manner in which the seditious transgression takes place in the work and how its author introduces profanation at different textual levels [see: Czapliński, p. 206].

Positively valued profanation halts subsequent repetitions of proper representations of the Holocaust and the resulting characteristic monotony of the literature of the Shoah, which invokes in the audience either a sense of "settlement" and listlessness, or weariness and dejection caused by the recognised form of a document/testimonial. Representations in which the authors prefer aesthetic value over ethical discourse and propriety or simply point to 
the inevitability of "aesthetic profanation", bring a chance for the renewal of the presence of the Holocaust in social communication, and-introducing new aesthetic forms - question and redefine the established canon schemes of representing a liminal experience.

Profanation as a model of representing the Shoah includes mostly the postmemory works of authors who seek their own individual way of confronting the experience of war artistically. This strategy was also assumed by Ewa Kuryluk: a painter, writer, essayist, and creator of installations, who dealt with family trauma in collages and photomontage. The collage technique is the guiding principle not only of Kuryluk's artistic installations, but also of her whole output, which combines three different types of representation: literature, photography, and fine arts. The network of mutual relations and references between the autobiographical literary texts, Goldi and Frascati, photos of Kuryluk's mother and Yellow Installations is so clear that it would be difficult not to read her works together. This is why in this paper I discuss different aspects of Ewa Kuryluk's artistic output, treating them, however, as elements of an ambiguous and interactive aesthetic whole.

\section{The crisis of representation}

In Ewa Kuryluk's art, the turn to the past and the interest in the family history has appeared most clearly since 2001, that is since the death of her mother, Maria Kuryluk (vel Miriam Kohany). For a long time, Ewa Kuryluk did not know that her mother was a Jew who had survived the war thanks to the help provided by her future husband, Karol Kuryluk. Maria Kuryluk hid her identity from her children and did not speak of her war experiences. Being unable to deal with the trauma of Shoah, she tried to suppress it and expunge the events of the past from her memory. Frascati contains this a statement of hers: "I used to try to convince myself that I had survived to bear witness. But the truth outgrew me - she moaned - it was easier to write propaganda. In the end, I survived to conceal-she hid her face in her hands" [Kuryluk 2009, p. 47].

The attempt to cut herself off from her traumatic memories is also expressed in the symbolic act of secreting her relatives' photos in shoes. Her acts are an absurd, yet paradoxical repetition of the gesture of Jews who hid their family photographs during the war. However, Kuryluk did not do that to maintain her memory of the pre-war world and the deceased, but mostly in order to escape the painful memories and the loss, to which she could not accustom herself. Therefore, she "squirreled away" her own memory, which made her similar to her family's hamster Goldi, which hoarded pieces of food for a later time. The analogy between the behaviour of the mother and the pet indicates that the hiding of the photographs has more than a univocally escapist dimension. 
And it does not release her from her past, which she might have managed by destroying or throwing them away. Kuryluk, like Goldi using the food that he she had squirreled away, would return to her "album" and supplement it with new pictures.

It was not until after her mother's death that Ewa Kuryluk found the shoes with the photographs in the apartment in Frascati Street. The pre-war pictures feature Miriam Kohany, her parents, Paulina Raaber and Hirsch Kohany, her sister Hilda and her brother Oskar, as well as her first husband Teddy Gleich. Several photos from the post-war period show mostly Maria Kuryluk with her children, Ewa and little Piotr. We may then observe that the photographs constitute a tale that the mother was not able to tell in words. The narrative emerging from the photographs is also a map of her memory-frayed, snippety, and unclear. It seems, therefore, that the testimonial left by the mother became an impulse for the artist: not only to learn or reconstruct the history of her own family, but to confront the trauma of war kept in her memory and to work it through on her mother's behalf, so to speak.

The photographs collected by Maria Kuryluk are incorporated by the artist both into her literary and Visual works. Creating her collages, Ewa Kuryluk exploits chiefly the critical capacity of collage, which is here aimed at traditional ways of creating a piece of art as a complete and coherent whole, updated in the face of the crisis of representation [see: Nycz, p. 216]. In Kuryluk's art, the insufficiency of the form of representation assumes an additional meaning because it is revealed in the context of attempts to confront a liminal experience and to learn the history of her predecessors. The lack of knowledge or uncertainty concerning the past of her own family entangled in the trauma of the Holocaust is best revealed in a chapter of Goldi entitled Kochani w butach mamy (literally: The Beloved Ones in My Mother's Shoes), where Kuryluk describes her mother's photographs and documents. It turns out that they raise more questions and doubts than concrete explanations:

In another picture, Paulina is accompanied by an elderly man with a beard. Her daddy Raaber: my grandpa? [...] And what about the elderly lady by the fireplace under the palm? This is also Paulina, probably in her apartment. The grandparents were registered at Biała, in 52 Komorowicka Street, but they also possessed a property - a plot of land, house, garden? - in 12 Graniczna Street. How do I know about this? From records drafted in the summer of 1944 concerning the assumption of Hirsch and Paulina Kohany's assets, who resided at Bielitz-Biała from "c. 1920" until "31 August 1939", by the German administration. Indeed, after that date, there was no more information about them [...] [Kuryluk 2004, p. 210].

The numerous questions and repetitions of the word chyba (perhaps) in the narrative are evidence of the opacity, ambiguity, and understatements of the photographs. The disappointment with the pictures and even the distrust in such a form of representation bring the author to the following confession: 
"I will not be bamboozled by any photograph! For instance, the pictures from the shoes (of this black girl with me and little Piotr) are blatant forgeries" [Kuryluk 2004, p. 218]. The pictures, deprived of any context or tale, require archaeological work consisting in a laborious search for archival documents and simultaneous making of conjectures and assumptions. They demand a commentary explaining the history behind them, e.g. in the form of quotes from the records discovered. This is why Ewa Kuryluk does not believe in the objectivism of photography: it may be easily questioned (e.g. in autobiographies), and at the same time, she recognises the lack brought about by a photograph deprived of its own context [see: Kuźmicz, p. 123]. A precise reconstruction of the family biography based only on the pictures from her mother's shoes proves to be an impossible undertaking. Thus, the photos become not only a material sign of void, loss and trauma, but also of the inaccessibility of the truth about what happened to the family during the war. But is archaeology the only stake for which Kuryluk plays this game of the (in)expressibility and propriety of representation?

\section{The multi-layered character of collage}

The photographs found in her mother's shoes become the basis for the collage technique used by Ewa Kuryluk in her literary texts and installations. Collage allows her to fill the blanks in the photographs by providing them with a verbal commentary (in the books Goldi and Frascati) and to supplement them with plastic representations.

Ryszard Nycz defines the collage quality of literature as

[...] a neo-avant-garde form of ostentatious satisfaction with the essential tendency in the output of the last years to transgress the boundaries of autonomous art and to reveal both one's own relations with historical reality-which is achieved by its documentary aspect (the radical representation of an object) — and one's own rootedness in the discursive universe of culture, which is, in turn, evidenced by the ostentatiously thematized intertextual aspect, brought to the foreground [Nycz, p. 222].

The documentary and intertextual character of a literary collage is achieved by the use of quotes and linguistic calques from other texts: literary, functional and documental, or so-called quotations from reality referring to the surrounding world. Quoting “another's speech" alone assumes two gestures: a repetition of a given utterance from a specific source and placing it in a new verbal context. This specific recontextualisation expands the semantic field of the quoted statement, gives it new meanings and connotations, and subjects it to the "estrangement effect" (Nycz, pp. 195-196; cf. Shklovsky, passim]. 
These elements of the collage character are a significant composition principle of Ewa Kuryluk's autobiographic works, Goldi and Frascati, in which the author returns to her childhood and describes it from a child's point of view. From the works emerges an image of a family that within the home organises its own world, which is in opposition to external reality. The isolation of the family world is emphasised chiefly by the use of a different language, which is understandable only for the family members, and by giving one another fictional pseudonyms. This nature of language comes to light even in the following statement of Karol Kuryluk in Goldi:

"Comrade Goldi", he sought him with his eyes but did not find him: Goldi was wrestling with a link. "You kleptomaniac! You pulled it out of your sleeve. Do you realise with how many fillips the jewellery theft is punishable with?" It stubbed you conciliatorily with its nose and looked at little Piotr, who squealed with joy: "Goldi! Comrade Ambassador was enrolled on your list for bicycle sport training" [Kuryluk 2004, pp. 138-139].

This intimate and slightly infantile language of family communication consists of animal metaphors, neologisms, diminutives, puns, and quotes from the newspeak of the Polish People's Republic. Let us remind the reader that Karol Kuryluk was a journalist and social activist, and - during the rule of Gomułka - the Polish People's Republic ambassador to Austria, minister of culture and the director general of Polish Scientific Publishers PWN. Therefore, the pastiche statements of the father refer to the communist reality and the socio-political situation in which he was entangled. The language, which oscillates between private and personal space on the one hand and the external on the other, has the aim of taming threat by laughing it off through fun and games. It also creates the illusion of an enclave, where one does not speak of such taboo subjects as experiencing the Holocaust, one's mother's mental illness, or the reality of the Polish People's Republic. The language of the Kuryluk family has, at the same time, a masking effect and leads to the suppression of voice [see: Szybowicz]. The existence of the trauma of the Holocaust (or the mother's photographs) that marked the whole family is neither conscious nor expressed by the family members. Nonetheless, the presence of the unfathomable secret triggers the affective potential. The tension between the inner urge to repress the trauma and the necessity to reveal it is constantly and subconsciously sensed by the housemates. The affective moments of the manifestation of the trauma take place in involuntary linguistic allusions and the mother's phobias (with the foremost imperative to hide). Monika Żółkoś points out that

[...] the mother, an escapee from the Lviv ghetto, lasts not in the living memory of that event but in the Holocaust made eternally present, making her Jewish origins the greatest of all mysteries, concealed even from her children. A mystery unspoken of for years, yet constantly present in their lives. An unnamed stigma, sensed 
and endlessly traced by the mother in real or imagined allusions of the milieu, in the anti-Semite linguistic fossils, the anti-Jew post-war tangles of Polish history [Żółkoś, p. 272].

The non-disclosure of these difficult experiences results in the creation of a net of allusions and understatements that indicate the affective-emotional burden of the mother's war experiences. In many situations, Maria Kuryluk repeats certain "affective structures" that are incorporated into the family idiom as an immanent element of it: "Eapka [En. Paw] took Niedobitek [En. Survivor] from a bench only in a sweater" [Kuryluk 2009, p. 14]; "Foolish nipper! They will make a lamp-shade of you" [Kuryluk 2009, p. 18]; "In a real park, one can hide_-she whispered_rest on a bench, drink from a spring, meet a man. A real park is a sheet anchor" [Kuryluk 2009, p. 64].

The colour yellow in Kuryluk's artistic output is also an allusive and affective symptom of the trauma, which operates in the artist's works and installations as a quote that refers to a cultural area. The cover of the first edition of Goldi, designed by Kuryluk herself, is yellow and the colour appears frequently throughout the whole book: "Yellow birds, yellow flower petals, yellow snowflakes. Yellow made my head spin" [Kuryluk 2004, p. 122]. This also plays a significant role in the series of Yellow Installations from 2001. In the opening composition Yellow Birds Fly, the artist creates paraphrases of the photographs she has discovered, in which the images of the deceased family members are cut out of yellow silk [see: Kuryluk 201, p. 5]. Ewa Kuryluk usually uses this colour because its connotations aroused in her mother the most (contradictory) emotions - on the one hand it was associated with the mother's favourite painter, Vincent van Gogh, and on the other it became a sort of fetish evoking traumatic memories and thus triggering strong aversion. The introduction of yellow hues and their meaning draws from the tradition and the cultural symbolical background in which yellow means, first and foremost, hostility, jealousy, betrayal, or exclusion from the community ${ }^{1}$. What is more, in Kuryluk's works, yellow also refers to the yellow armband with the Star of David that her mother was forced to wear during the war. The meaning of the colour may, therefore, be related to the trauma, the experience of exclusion and the Extermination of the Jews [see: Kuryluk 2005, p. 185]. It is also worth mentioning that the problem of exclusion, which appears in the installations, is symbolised not only by the colour yellow, but also by the contour characteristic of the pictorial paraphrases of photographs that separates and marks the object represented. Since the characters featured in Kuryluk's installations are the ghosts or shadows of her predecessors, the contour of these images is

1 "In France, the door to the apartment of a person convicted of adultery was painted yellow. In the $16^{\text {th }}$ century, the Hamburg prostitutes had to wear yellow scarfs. In some countries in the middle ages, Jews were forced to wear a yellow hat, cloak and a yellow patch on their clothes [...]" [Kopaliński, p. 513]. 
neither clear nor precise, which enables her to emphasise the impossibility of true knowledge and the representation of the past.

The repression of trauma from a language and protecting people (not only children) from direct confrontation with the dramatic events proves impossible: little Piotr and Ewa sense and take over their parents' experiences. They quickly adopt the rules of concealing and camouflaging the truth from one another, they learn the home language and begin to use its verbal allusions. In Goldi, we can read:

It was already winter and it was snowing, when I spoke at last:

"Lapka", I sat on your lap and stroked your cheek, "where is... Ma-daa-gas...?"

"I stopped because you froze all over" [Kuryluk 2004, p. 118].

The children are involuntarily included in the community of the Holocaust experience, which also begins to have an effect on their psyche and behaviour:

"What did little Piotr take fright of?", Łapka asked me in the evening.

"The hairdresser".

"Is he afraid of the white apron because it reminds him of a doctor?", he sorrowed. But he would have sorrowed even more if I had told him that little Piotr was terrified of the hair on the floor [Kuryluk 2009, p. 103].

It seems the homely idiom, which lost its socio-political context actualised mostly by the father, is included by Ewa Kuryluk in her own postmemory narrative about the family trauma and about transgressing it. The attempts to break the taboo that "preserve" the family trauma also appear in the 2005 installation entitled Tabuś. Tabuś, according to a tale told by the mother, was a "marmot adopted from the eastern slope. It has paralysed paws and blind eyes", she has closed its eyes, 'and a quilted head' she fingered its temples, 'and it does not have a tongue. But it is mostly downy and sits in a pushcart in the place of honour"' [Kuryluk 2004, p. 97]. Tabuś may then be regarded as the alter ego of Kuryluk's mother, who cannot find the proper language to tell her experiences. In this quotation from Goldi, as well as in the title of the installation, there are diminutives and litotes, common in Kuryluk's works, which narrow the view to a certain space, language and circle of characters. The impression of the minimisation of the homely world results not only from taking a child's perspective (together with all its limitations), but also from the will to tame what's happening under the surface of words, gestures, or behaviours. From getting closer to the unknown and directly inexpressible. The wish to reconstruct one's childhood space is filled with hiding places (e.g. a wardrobe, an unlit bathroom) and does not bring the sense of claustrophobia which was present in the mother's world. It seems that in Kuryluk's works the device of minimisation serves the construction of an intimate world treated with exceptional affection and warmth but also informs one of the private character of the family trauma. 


\section{The bricoleur strategy}

Using previously developed materials in her works or referring to elements that earlier appeared in a different context, Ewa Kuryluk as a collage artist assumes a specific position of bricoleur. An artist who takes on this new role

[...] has to turn back to an already existent set made up of tools and materials, to consider or reconsider what it contains and, finally and above all, to engage in a sort of dialogue with it and, before choosing between them, to index the possible answers which the whole set can offer to his problem [Lévi-Strauss, p. 18].

Such a strategy allows her to blur the earmark of the artist's individualism, which in Kuryluk's case seems to be particularly important as it enables her to listen intently to the voice of direct witnesses of the Holocaust and thus makes her attempt to become familiar with her family possible.

For Kuryluk's works are not only about the reconstruction of her predecessors' history, but also about the symbolical restoration of the family bond and the possibility of meeting her close relatives. It appears that in her installations Kuryluk celebrates an endless rite of dziady [an ancient Slavonic feast commemorating one's ancestors-K. S.], during which she tries to sense the presence and closeness of those of her ancestors that she was not able to meet, and to find a bond with them that could not have existed in reality. This process of constructing a kind of analogy between her own life and the history of her forebears, as well as her attempt to represent her family experience are shown in a collage entitled Ship created in reference to Maria, Piotr and Ewa's stay by the Black Sea. It seems, however, that it was directly inspired by the artist's dream described in Frascati:

That night, mum slept like a log, little Piotr wept, and I dreamt of a ship. No, not theirs: ours. On the mast, a flag with the inscription "Frascati" was fluttering, the wind inflated the sails made of yellow silk, embroidered by mum with blue tulips. For half a century, the dream recurred in various versions. The ship resembled a toy, while little Piotr and me - cut-outs of silk [Kuryluk 2009, p. 18].

The Ship installation is a precise realisation of the dreamy vision of the ship on which the artist meets dead members of her family. As Ola Wojtkiewicz observes:

This symbolic ship comes from the medieval practices of proscribing lunatics: ships with "madmen" were launched without food or water, which was virtually a death sentence for the passengers. The artist regards her Ship to be "a dream, born from grief, about a meeting with the dead in the blaze of eternity" [Kuryluk 2011, p. 19].

In this representation, the artist clearly refers to the tragic fate of her predecessors. What is more, she suggests that the feast of dziady becomes a vital element in the process of mourning close relatives and getting over one's loss. 
In the installations, the dead are accompanied by cut-outs of the children, Piotr and Ewa, the heirs of the Holocaust legacy. In Tabuś, Kuryluk included two matches: of the silhouette of Anne Frank (from a picture preserved by her mother) with little Piotr's face, and of Anne's friend with her own face. Additionally, the multiple "assembled characters" of little Piotr form a smoke trail-it would be difficult not to perceive it as a reference to smoke escaping crematoria. What is striking about these matches is the implied (also by Kuryluk's mother who put this photograph cut out of a newspaper in the family "album") parallel of the fate of the children of Shoah or the Jewish community in general and the life of children born after the war with the traumatic burden of their parents. Here comes to light the awareness of her own potential fate as a Jewish child, only born in more favourable times, and the conviction of the constant presence of the Holocaust, even if at a different level — of postmemory and ideas.

It is worth asking why Kuryluk attempts to consolidate her grandparents' biographies and to get to know her forebears. Does she only do this so that through her cognition and artistic elaboration she saves the family history from oblivion, that is, to make her artistic output "the place of contemplation in the face of death and imminent forgetting" [Szymański, p. 146]? We should note that in her works Kuryluk actually shifts the accent from telling particular tales of her forebears to the very process of reconstructing the past. For her, her family history, therefore, becomes "in fact a tale about a bond and, in some aspects, about permanence and continuity. Importantly, it is also a tale about a community, in which and thanks to which one may build oneself" [ProkopJaniec, p. 123]. In this way, the author seeks her own manner of dealing with her family trauma and, first and foremost, to reconstruct her own identity. In Ship, she shows people connected with each other not only by a family bond, but mostly by the stigma of the Holocaust; she also places herself among the numerous characters. Consequently, the position of a bricoleur assumed by Kuryluk, is founded on an interactive and live dialogue with individual elements of the collage and implies that they have a meaning: the very selection and arrangement of the cut-outs in a particular sequence entails a specific reflection. Therefore, bricoleur does not take a position distanced from the collage but places hers within it [see: Nycz, p. 204].

The act of receiving the trauma is also shown by Ewa Kuryluk in the 2011 installation Konik, which reproduces her mother's dream, in which she led Ewa and little Piotr on a pony to grandma Paulina Kohany, killed in the Treblinka extermination camp. The children and the mother are connected by a blue ribbon, which apparently refers to the red thread from Kuryluk's earlier paintings, where it marked life, blood, but also femininity and the constant possibility of pain [see: Arno, p. 116]. In this installation, the ribbon gains an additional meaning: one may think that in this context it becomes the sign of the mother's memory "wrapped" in trauma, which also entangles her children. 
This is evidenced by the artist's brother's fate: little Piotr, an exceptionally sensitive and talented boy, "fell ill with Holocaust". Being unable to deal with the difficult memory, he repeatedly attempted suicide. The trauma marked Ewa Kuryluk too, as "the legacy she found in the wardrobe is almost literally harnessed in her art, both at the level of reference and in the performative sense" [Głowacka].

The blue ribbon may also indicate the author's identification with her mother's war trauma and that she shares her tragic experiences. A postmemory reworking of the experience of the Holocaust is emphatically presented in the fabric of Triptych on a Yellow Background, which consists of a combination of two photographs: the face of Miriam Kohany from 1943 and the body of Ewa Kuryluk wearing clothes that her mother could have worn at that time, as well as the artist's self-portrait in her father's cloak and shoes. In this scene, the artist plays the role of her mother, who sits on a bench in Stryjski Park after she had escaped from the Lviv ghetto and received no help from her paid friends, as well as the role of her father heading to her mother. Importantly, the author of the work learned about the history of her parents' meeting from a recollective text Muzyka dla Karola (literally: Music for Karol) written by Zofia Lissa and dedicated to the memory of Karol Kuryluk [see: Kuryluk 2011, p. 25]. Impersonating the character of her mother and father in an artistic performance, which is indicated by the symbolic meaning of wearing her parents' clothes, is evidence of her identifying with their experiences, but also of her attempt to verbalise the concealed narrative on their behalf. Having no access to any direct account of this event, in Triptych on a Yellow Background, Kuryluk builds mostly upon her imagination.

\section{Conclusions}

The collage created by Ewa Kuryluk, in which various forms, namely literature, photography, and plastic arts, mutually complement one another claims to be a comprehensive project (or maybe a complete work of art). Not only do the elements of collage have an important function for the shape of individual works, but they are also consolidated in an aesthetic whole. According to Marta Cuber, Kuryluk's literary and artistic output is positioned between documentality and fictionality, and as such it transgresses the boundaries of the colloquially understood properness in speaking of the Holocaust. Kuryluk creates a "masked card file", where she collects "conspirational facts" and documents that are mystified and assembled. Consequently, as Cuber implies, "the shift of energy from bearing witness to pretending that she is not enduring it made Kuryluk's works a gallery of unclear eccentricities and implicit ambiguities" [Cuber, pp. 134-135] which blurs the image of the reality invoked by memories and reveals it only in fragments and scraps. 
It seems, however, that Kuryluk's artistic output has almost no documentary value or that her attention is not, in fact, focussed on it. Aesthetic forms reveal the opportunity to listen intently to the crippled voice of her mother and at the same time to formulate her own reply to it. Does Kuryluk's collage profane the Holocaust? Yes, because it seems that the author could not do otherwise. In her artistic strategy of a bricoleur, Kuryluk often follows traces of her imagination, recalls mostly scenes from the past that could have happened, or fills the gaps in the tales known only in obsolete and dispersed forms. Her artistic output cannot be faithful to the postulate of reliability and properness of the narrative about the Holocaust because it is sentenced to potentiality, wandering among the insufficient media of the past, and eventually, mediated access to the family history. Going beyond this ethical oppression by creating matches and multiple cut-outs frees the representation which in turn enables one to approach the experience of trauma. What is more, overstepping the boundaries of propriety is a result of an authentic search for a new language and rhetoric. Therefore, the profanation of Shoah committed by Kuryluk becomes necessary in order to break the taboo of Jewishness and the Holocaust.

\section{Literature}

Adorno, T. W. (1967). Prisms. Transl. by S. and S. Weber. London: Neville Spearman. Ankersmit, F.R. (1997). Remembering the Holocaust: Mourning and Melancholia. In: P. Ahokas, M. Chard-Hutchinson, eds. Reclaiming Memory: American Representations of the Holocaust. University of Turku.

Arno, A. (2011). Skóra. Opcje 1-2.

Cuber, M. (2011). Hologramy Zagłady. Opcje 1-2.

Czapliński, P. (2009). Zagłada i profanacje. Teksty Drugie 4.

Głowacka, D. (2009). Świadkowie wbrew sobie: strategie pamięci Holokaustu w twórczości plastycznej kobiet “drugiego pokolenia”. [online] Artmix. Available at: http://archiwum-obieg.u-jazdowski.pl/artmix/14392 [Accessed: 15 Dec. 2014].

Hirsch, M. (2012). The Generation of Postmemory: Writing and Visual Culture after the Holocaust. New York: CUP.

Kopaliński, W. (2001). Słownik symboli. Warszawa: Rytm.

Kuryluk, E. (2004). Goldi: Apoteoza zwierzaczkowatości. Warszawa: Twój Styl.

Kuryluk, E. (2005). Podróż do granic sztuki: Eseje z lat 1975-1979 i eseje z lat późniejszych na ten sam temat. Warszawa: Twój Styl.

Kuryluk, E. (2009). Frascati: Apoteoza topografii. Kraków: Wydawnictwo Literackie. Kuryluk, E. (2011). Żólte instalacje 2001-2011. Commentaries by O. Wojtkiewicz. Katowice and Gliwice: Stowarzyszenie Inicjatyw Wydawniczych.

Kuźmicz, M. (2011). To, co ukryte: O relacji malarstwa i fotografii w twórczości Ewy Kuryluk. Opcje 1-2. 
Lévi-Strauss, C. (1968). The Savage Mind (La Pensée Sauvage). $2^{\text {nd }}$ ed. London: Weidenfeld and Nicolson.

Nycz, R. (1993). O kolażu tekstowym: Zarys dziejów pojęcia. In: Idem. Tekstowy świat: Post-strukturalizm a wiedza o literaturze. Warszawa: Wydawnictwo IBL PAN.

Prokop-Janiec, E. (2001). Żyd - Polak - artysta: O budowaniu tożsamości po Zagładzie. Teksty Drugie 1.

Shklovsky, V. (2017). Art As Device. In: A. Berlina, ed. and transl. Victor Shklovsky: A Reader. New York: Bloomsbury Academic.

Szybowicz, E. (2011). Bratnie łapki. [online] Dwutygodnik. Available at: http://www. dwutygodnik.com/ artykul/2111-bratnie-lapki.html [Accessed: 16 Dec. 2014].

Szymański, W. (2011). Głęboka jest studnia przeszłości. Opcje 1-2.

White, H.V. (1975). Metahistory: The Historical Imagination in Nineteenth-Century Europe. Baltimore and London: John Hopkins University Press.

Zaleski, M. (2009). Słowo zapomniane? [online] Dwutygodnik. Available at: http:// www.dwutygodnik.com/artykul/360-slowo-zapomniane.html [Accessed: 15 Dec. 2014].

Żółkoś, M. (2011). Tworzenie pamięci: O powieściach autobiograficznych Ewy Kuryluk. In: R. Nycz, Kultura po przejściach, osoby z przeszłością: Polski dyskurs postzależnościowy - konteksty i perspektywy badawcze. Kraków: Universitas. 